\title{
“THE NUN'S PRIEST'S TALE” AS AN INTERROGATIVE TEXT: Chaucer's Invitation to Examine Patriarchal Christianity
}

\section{Benjamin Moore}

All Language, Argues Catherine Belsey in her book Critical Practice, bears an explicit or implicit relation to the ideology out of which it arises, and the study of literature must somehow address this relation. Belsey thus outlines a new classification of texts based upon a text's approach to the reader in regard to a particular dominant ideology. In addition to the declarative text, which imparts an ideology, and the imperative text, which induces in the reader struggle against an ideology, Belsey describes and examines the interrogative text, which causes the reader to question both the means of construction of the text and the ideology out of which the text arises. Drawing upon the work of Steve Neal and Emile Benveniste, Belsey writes:

The interrogative text ... disrupts the unity of the reader by discouraging identification with a unified subject of the enunciation. ... The position of the "author" inscribed in the text, if it can be located at all, is seen as questioning or as literally contradictory. Thus, even if the interrogative text does not precisely, in Benveniste's terms, seek "to obtain some information from the reader," it does literally invite the reader to produce answers to the questions it implicitly or explicitly raises. (Belsey 91 )

The interrogative text accomplishes this goal by drawing attention to its own textuality, thus intermittently undermining the unified illusion which might otherwise be set forth in the work. This disruption also prevents the dominance in the text of a privileged voice or discourse which "contains and places" any fragmentation of the text's discourse and meaning. Since the work's textuality is apparent, and since there is no central authority in the text directing textual meaning, the reader is invited to contemplate both the dominant ideology and the way it is embodied in language.

I feel that such a critical approach, which allows recognition of failures as well as successes in both ideological and literary coherence, is potentially applicable to several of the Canterbury Tales, since many 
of the tellers of the tales concern themselves in one way or another with questions of doctrine-that is, ideology. ${ }^{1}$ Such an approach is also contrary to approaches in the larger body of standard Chaucer criticism. Critics of the "Nun's Priest's Tale" tend to presuppose a striving for coherency in the tale, attempting to unify plot, thematics, and language under an interpretation which seeks to resolve contradictions and problems of construction in the work. Typical of this approach are the works of J. Leslie Hotson, who sees the tale as an allegory for the murder of the Duke of Gloucester, and John Speirs, who interprets the "blithe, witty and wise tale" as an allegory of the fall of man resulting from the deadly sin of pride (Speirs 185-193). Certainly it is valid to investigate whether the "Nun's Priest's Tale" lends itself to such unity. Yet equally valid, I believe, is the attempt to examine the tale, including its dramatic frame of Prologue and Epilogue, as an interrogative text, probing its fissures of construction and consequent problematic of doctrinal meaning. Because the "Nun's Priest's Tale" posits a relation between language and ideology, draws attention to its own textuality, and openly calls for an examination of the doctrinal teachings underlying the Priest's performance, we as readers are invited to reflect upon the tale's linguistic construction and its relation to the dominant Christian ideology. As a result, inconsistencies within the tale become apparent, causing us to question both Christian doctrine and the Priest's patriarchal authority.

A brief examination of the Priest's relation to his tale suggests in itself the interdependence of the dominant ideology, or patriarchal Christianity, and linguistic constructs. The Priest, as a spokesman for Christianity, is clearly in a position of ideological authority. Obviously the content of the tale will therefore be measured against what a priest is expected to say - that is, against Christian doctrine. In other words, a representative of Christianity will produce the tale, and the tale in turn will become a resource for examining both Christianity and the doctrinal authority of the Priest. In addition, the Priest's authority is social as well as doctrinal, since he occupies a specified ideological function in his society that he can only fulfill with society's cooperation. Thus his own narrative ability, as the context of the story-telling contest reminds us, is important in determining the degree of respect that he will be able to command of his companions. The telling of his tale is thereby likely to either strengthen or undermine his social as well as doctrinal authority.

Emphasizing the relation of the Priest to his fiction is an implied identification in the tale between the Priest and Chauntecleer. Chauntecleer's sexual dominance over Pertolete, and indeed his sexual prowess in general, is a central feature of the story. The Host 
alludes to this aspect of the tale in his praise of the Priest's tale-telling ability, thereby drawing the Priest and the tale together through the comparison:

\footnotetext{
"Sire Nonnes Priest," oure Hooste seide annon,

"Iblessed by thy breche, and every stoon!

This was a murie tale of Chauntecleer.

But by my trouthe, if thou were seculer,

Thou woldest been a trede-foul aright.

For if thou have corage as thou hast myght,

Thee were nede of hennes, as I wene,
}

Ya moo than seven tymes seventene." [11. 3447-54.]

It is perhaps illustrative of our understanding of the comparison that the rooster or cock, according to The Dictionary of Symbols, has been a symbol for masculinity since ancient times (De Vries 104). Also, the $O E D$ testifies that "cock"-used in reference to Chauntecleer more than once-could in Chaucer's day refer to "One who arouses slumberers; applied to ministers of religion." The term also existed in the fourteenth century as a perversion of the word "God," the intermediate form being "Gock." (One also wonders if the word afforded Chaucer a chance for some really prurient punning; however, disappointingly enough, the OED does not mention a usage of the word to mean "penis" occurring until 1730 (OED 565-67).

The Host's comparison is of course not without irony and humor, since the Priest is supposed to remain celibate. But this irony asideand it is more easily set aside since the Host himself mentions the Priest's chastity - we may see in the favorable comparison the interrelations of the Priest's masculinity, his tale-telling, and his authoritative position in society. If we believe the Host to be a credible indication of social response, then the compliment of the Priest's masculinity affirms, at least on the surface, both the success of the Priest's tale and his authority in the social order; we are left to infer that authority's dependence upon the Priest's use of language. Furthermore, the praise of the Priest's masculinity is particularly appropriate in underscoring both the patriarchy in Christianity and the exclusively masculine authority which his position entails. The apparent success of the story is the apparent success of patriarchal Christianity; balls and doctrine together are blessed. The comparison thus heightens our awareness of the tale's origin in the dominant Christian ideology. And since the emphasis of masculinity in the tale reflects the Priest's own maleness, it also reminds us that the tale may tell something of the teller-or, to put it another way, that the product possesses a capacity to give insight into its means of production. The tell-tale tale-telling, then, allows us to approach the tale as both a 
product of the dominant ideology and a means of examining that ideology.

It may of course be argued that the Host is praising the man without regard to his status as Priest. And it is wise to recognize that the situation is complicated by the fact that the Priest as a human being may not always coincide with the abstraction of priest as pure ideological authority; the Priest's audience was no doubt well aware of this. But this recognition need not diminish our awareness of the tale's relation to ideology. Regardless of his own intentions in telling the tale-and humor is doubtless one of them-the Priest necessarily represents and embodies patriarchal Christianity. Despite whatever we might infer about the Priest's character, he is nonetheless frocked, and Chaucer has nonetheless chosen to put ecclesiastical words into the tale-teller's mouth. For us as readers as well as for the Priest's audience, doctrine is present whenever the Priest speaks, as the continual reappearance of doctrine in the story reminds us. It is thus difficult to evade the interrelation of the Priest's performance and Christian doctrine.

The awareness of the tale's status as linguistic construct arising out of a particular ideology is heightened by the tale's capacity to make us conscious of its textuality, both implicitly through its structural features and explicitly through the interjections of the narrator. This consciousness of textuality causes the reader to be distanced from rather than drawn into a fictional world. The genres utilized most often in the narrative-mock heroic, beast epic, and animal fable ${ }^{2}-$ immediately call attention to the fictionality of events through their self-consciousness and artificiality. The combination of these genres in the narrative thus creates distancing effects through two devices, parody and impossibility. The ridiculousness of a heroic chicken disallows us from identifying to any significant extent with Chauntecleer's plight, while the impossibility of animals' dreaming, speaking or thinking reminds us of the tale's fictionality in every step of the narrative. Again, the technique is not without its humorous results, but to say that the Priest is merely telling a funny tale is to evade the question of the tale's relation to his ideological position. Humor itself, in fact, may also be thought of as a distancing device, since it displaces emotional involvement in Chauntecleer's plight.

This already complex narrative structure becomes even more variegated-and more ridiculous - with the intrusion of other discursive forms, notably the philosophic dispute between Chauntecleer and Pertolete and the doctrinal digression and sermonizing interjected by the Priest. These intrusions, though partially attributable to the medieval tendency towards compilation, are purely the invention of Chaucer, occurring in none of his sources for the tale (Sisam). Despite 
the fact that they are marginal to the story itself, the intrusive forms actually form the bulk of the text; as Kenneth Sisam has determined, only about a fifth of the lines in the tale are devoted to the actual development of the plot (French 262-63). The often jarring conflation of the various linguistic forms allows for anything but a smooth passage through the narrative, since we are alternately bounced between narrative and the promulgation of doctrine. The insertions thereby disrupt any unity inherent in the development of the plot. The various formal irregularities, then, call attention to the tale's construction, virtually obliterating the possibility for the reader's absorption into the tale. Because such a means of constructing the tale interferes with our identification with events, we remain more intellectually than emotionally engaged. Moreover, the combination and interjection of various linguistic forms disallows any single discourse from being dominant, since no one linguistic form completely unifies the tale. We are thus not only more aware of the tale's existence as linguistic construct; we are also refused the direction of meaning that a unifying discourse would offer in its control of the narrative.

Perhaps some of the most important of these interruptions are the explicit references to the tale's textuality offered by the narrator himself, some of which are a playful recognition of fiction's ability to intellectually seduce the reader:

Now every wys man, lat him herkne me;

This story is also trewe, I undertake,

As is the book of Launcelot de Lake,

That wommen holde in ful greet reverence.

Now wol I torne agayn to my sentence. [11. 3210-14]

O Gaufred, deere maister soverayn,

That whan thy worthy king Richard was slayn

With shot, compleynedst his deeth so soore,

Why ne hadde I now thy sentence and thy loore,

The Friday for to chide, as diden ye?

For on a Friday, soothly, slayn was he.

Thanne wold I shewe you how that I koude pleyne

For Chauntecleeres drede and for his peyne.

Because these reminders point up the relation between teller and tale, we are conscious not only of textual illusion but also its methods and purposes. We wonder why the narrator is producing fictionality and what he is doing to produce it. And again, since the narrator is a Priest, we are given cause to reflect upon the relation of fiction and ideology. Thus the self-consciousness of the narrator heightens the effect of the opacity of his text, further discouraging us from accepting the textual illusion as truth.

The implied relationship in the tale between language and ideology 
and the tendency of the tale to call attention to its own textuality are in themselves enough to establish "The Nun's Priest's Tale" as an interrogative text and cause the reader to contemplate the tale's relation to ideology. However, the full magnitude of the tale's invitation to the reader does not become present until the end, when the Priest suggests, without specifying, an intended relation in the tale between language and doctrine. The Priest calls to our attention both the element of animal fable in the tale and his own position of doctrinal leader by emphasizing the tale's doctrinal importance:

But ye that holden this tale a folye,

As of a fox, or of a cock or hen,

Taketh the moralite, goode men.

For Saint Paul seith that al that writen is,

To oure doctrine it is ywrite, ywis;

Taketh the fruyt, and let the chaf be stille.

Now, goode God, if that it by thy wille,

As seith my lord, so make us alle goode men,

And brynge us to his heighe blisse! Amen. [1l. 3438-46]

Such a closure in the fiction purports to be disclosure of doctrinal meaning, and we are in fact given just prior to this ending a moral of sorts: "Lo, swich it is for to be recchelees / And necligent, and truste on flaterye" (1l. 3436-37). However, it is difficult to imagine that the Priest's performance, packed as it is with doctrinal digression and assertion, can be limited to this moral alone, especially considering the sweeping definition of the relation between text and "al that writen is," which immediately follows. There are instead a multitude of doctrinal messages, and we are not content to recognize only one. On the other hand, we are not told explicitly at the end which ones to remember, either. In the tale's final moments, then, the reader is discouraged from immediately identifying with the authoritative voice of the narrator. Instead, the apparent closure is left partially open, and the tale's conclusion interpellates us as readers with regard to the dominant ideology, inviting us to reflect upon the relation between textual matters and Christian doctrine. The invitation is, of course, particularly efficacious since the tale has already prepared the way for such consideration by the various ways in which the tale has made us aware of ideology and textuality. Because we must now look to the text to find doctrinal meaning, we begin our examination of the way the tale deploys ideology.

Because the tale is in part a fable, we are first likely to look to the events of the narrative for an understanding of the tale's doctrinal meaning. The various instances of moralizing by the Priest are further possible evidence for determining the tale's ideological disclosure. Such a search is not without its rewards; in fact, part of the difficulty 
lies in the fact that there are so many implicit directives, it is impossible to definitively separate the fruit from the chaf. Judging from Chauntecleer's plight alone, we may determine a minimum of seven morals. Don't be “recchelees" or hasty. Don't take advice from a female. Always pay attention to your dreams. Stay close to home where it's safe. Beware of flattery. Yield to your natural fears. Keep your mouth shut. The Priest's own commentary yields a minimum of two more: worldly joy perishes (1l. 3205-06), and what God foresees must be (1. 3234). The Priest also expands upon doctrine implied by the plot, notably the misogynistic theme (1l. 3252-66). Chauntecleer himself adds an extraneous moral in his own exempla: murder will out (1. 3052).

Further doctrine is suggested by the philosophical dispute between Pertolete and Chauntecleer, which can be interpreted as a debate between science and authority, and by extension between skepticism and doctrine. Skepticism argues for a causal explanation of dreams, while doctrine upholds dreams' relevance by appealing to authority in various exempla. Implicitly, we are instructed to favor doctrine, since Chauntecleer's nightmare eventually comes true. In this light, we can view Chauntecleer's capture by the fox as a result of his failure to yield to the instruction of the authorities to which he so facilitously alludes in the dispute. Yet another, perhaps a more universal moral thereby becomes evident: trust authority. This affirmation of authority lends perhaps some unity to the tale's doctrine, since it would uphold all of the morals expressed in the tale. However, even this unity is only weakly implied, especially considering that the narrative could well exist without the philosophic dispute. At best we can determine that the doctrine of the tale is a loose alliance of morals that is centered upon Chauntecleer's misfortune.

The tale's status as an interrogative text, however, results in a disruption of even this uneasy coherence of meaning. Since the tale's refusal of explicit disclosure causes us to more closely examine its interrelation of language and doctrine, we are more likely to examine its fissures as well as coherences. Thus a closer examination of events in the narrative, especially events that appear to be secondary to the mainstream development of events, reveals contradictions within the doctrinal implications of the tale. Importantly, these contradictions serve to unseat both misogynistic doctrine and the masculine authority of the Priest, further calling into question the doctrines of patriarchal Christianity.

The relation between the Priest's narrative and his misogynistic doctrine is obvious. For example, Chauntecleer is imperiled because he yields to the advice of Pertolete. The Priest is thus able to set forth 
one of his strongest admonishments, to shun the advice of a female:

My tale is of a cok as ye may here,

That tok his conseil of his wyf, with sorwe,

To walken in the yerd upon that morwe

That he hadde met that dreem that I yow tolde.

Wommennes conseils been ful ofte colde;

Wommannes conseil brought us first to wo

And made Adam fro Paradys to go ... [3252-58]

It is worth noting that this invective is completely in keeping with both the Priest's position in the patriarchal ideological order and his concluding reference to St. Paul, who himself made outspoken attacks upon the status of women. ${ }^{3}$ The Priest's ability to explicitly integrate the events in the tale with Christian misogyny is also another reminder of the interrelation between his tale and his function as doctrinal authority. On the surface the tale supports the misogynistic position. But we must also recognize that Pertolete can be credited with saving Chauntecleer's life by calling attention with her shrieking to Chauntecleer's abduction; if women were always to remain silent, as the Priest would most likely wish, Chauntecleer would be dead. The idea of the ineffectuality of women is further subverted by the fact that women"This sely wydwe and eek hir doghtres two"-lead the chase after the fox (1l. 3375-82). This passage also serves to remind us that the "tredefoul" is merely the personal property of an old widow. Thus foregrounding these events, which are crucial to the tale's development despite their brief treatment, calls into serious question the coherence of the tale's misogynistic assertions.

The tale further disrupts ideological coherence and the patriarchal authority of the Priest in the character of Chauntecleer himself, since it is largely Chauntecleer's machismo-the very quality for which the Priest is praised in the Epilogue - that gets him into trouble. Certainly a major motivation for Chauntecleer's scorning the prophecy of his dream is Pertolete's attack upon his masculinity:

"Avoy!" quod she, "fy on yow, herteless!

Allas," quod she, "for, by that God above,

Now han ye lost myn herte and al my love!

I kan not love a coward, be my feith!

For certes, what so any woman seith,

We alle desiren, if it myghte bee,

To han housbandes hardy, wise, and free ..." [11. 2907- 14]

Lest we too hastily interpret Chauntecleer's ensuing carelessness as a result merely of being henpecked, we must also consider the readiness with which he abandons his doctrinal position in his philosophic dispute with Pertolete for a morning of feathering, treading, and strutting his stuff (ll. 3177-81). In his desire to bed down with Pertolete, he is even able, through either design or ignorance, to 
twist the meaning of Mulier est hominis confusio by translating it as "Womman is mannes joye and al his blis" (ll. 3163-66); not even proverbial wisdom will stand in the way of our aroused chicken. Furthermore, Chauntecleer's male ego is not provoked by Pertolete alone, since he again falls victim to his masculine vanity in his confrontation with the fox. The fox sways Chauntecleer off his guard by asking Chauntecleer to demonstrate his singing ability, which in the context of the tale is an especially masculine attribute fundamental to the status of a "tredefoul." As a result, Chauntecleer literally sticks his neck out in order to uphold his masculinity. Thus Chauntecleer's position of masculine dominance paradoxically leads him to a position of vulnerability; the basis of authority is also a basis of weakness. Once this fact is obviated, it is difficult to see either the Priest's misogynistic thesis or his partriarchal dominance being implemented or illustrated in the tale. Causal coherencies in the plot indicating an affirmation of the dominant ideological order are clearly contradicted.

It is at this point possible to see the final and perhaps the most important contradiction, the one between the Priest and his tale. Remembering the Host's favorable comparison of the Priest to Chauntecleer, we can draw further parallels between the storyteller and the character he creates, many of which are perhaps not so complimentary. The Priest, like Chauntecleer, is atttempting to assert his dominance with the superiority of his "singing," or storytelling, perhaps even sticking his neck out, since he could fail as well as succeed. He is also in the position of being under a kind of ownership by a woman, since he is serving the Prioress in his capacity of priest. If we are to draw any sort of parallel between the Priest and his fiction, as the Host himself does, then we are likely to question the basis from which the Priest's patriarchal authority is asserted. It is thus not at all certain that the storytelling affirms the Priest's authority, any more than it is certain that the ideological implications of the narrative ultimately support patriarchal Christianity. In fact, the Priest as taleteller may be seen to contradict the Priest as authority, since his product does not support in a coherent fashion his own embodiment of doctrine, as it purports to do. Thus the relation between Priest and tale is split apart, and in this gap we find our final and perhaps most important opportunity to reflect upon the dominant ideology, or even, if we wish, to construct a critique of it.

Chaucer's work does not, of course, indicate the answers to such questioning, nor does it engage in its own critique of patriarchal Christianity. To do either would be to provide the text with yet another discourse, one that directs meaning either parallel with or against the dominant ideology. Were this discourse present, the text 
would not be interrogative at all, but rather either declarative or imperative. Nor does the tale itself posit a readily identifiable irony which allows us to write off the tale as only a parody or burlesque. Even if we say that the Priest willingly ironizes himself in telling a funny, somewhat bawdy story, we still cannot dismiss the fact that he embodies the dominant ideology, nor can we escape the questioning of ideology that his story entails. Humorous moments certainly abound, but the stake of the Priest's own authority in his performance, not to mention his serious doctrinal assertions, counter and contradict a unity of lightheartedness. Thus not even ironic discourse is coherent enough to control and place meaning in the tale. As a corollary to these observations, we must also recognize that any "meaning" we get out of the tale beyond the invitation to reflect is of our own construction, since the only position of intelligibility offered to the reader is an actively critical one. The tale's inconsistencies, then, constitute Chaucer's narrative success. The tale actively engages the reader in critical consideration in a way that a closed didacticism could never accomplish.

\section{NOTES}

1. In addition to the "Nun's Priest's Tale," the "Prioress's Tale" and the "Wife of Bath's Tale" are notable examples.

2. For a concise description of the conventional structures utilized in the tale, see Robert Dudley French, A Chaucer Handbook (New York: F.S. Crofts \& Co., 1939), pp. 257-65. A more detailed if perhaps less elucidating study of the topic is available in Kate Peterson, On the Sources of the Nun's Priest's Tale (Boston, 1898).

3. For a thorough discussion of the Priest's misogyny, see R. M. Lumiansky, Of Sundry Folk: The Dramatic Principle in the Canterbury Tales (Austin: University of Texas Press, 1955), pp. 105-17. Lumiansky's approach is to find psychological motivations on the part of the Priest for telling the tale. He argues that the Priest's "anti- feminism" is largely a reaction to his serving under the "petticoat rule" of the Prioress and involves a projection of his masculinity into the tale. While I find many of Lumiansky's observatiions convincing, I again feel that he presupposes a unity with this approach, consequently failing to treat contradictions of the misogynistic doctrine within the tale.

\section{WORKS CITED}

Belsey, Catherine. Critical Practice. New York: Methuen, 1980.

De Vries, Ad. Dictionary of Symbols and Imagery. Amsterdam: North Holland Publishing Company, 1974.

French, Robert Dudley. A Chaucer Handbook. New York: F. S. Crofts \& Co., 1939.

Hotson, J. Leslie. "Colfox vs. Chauntecleer." Chaucer: Modern Essays in Criticism. Ed. Edward Wagenknecht. New York: Oxford University Press, 1959.

Lumiansky, R. M. Of Sundry Folk: The Dramatic Principle in the Canterbury Tales. Austin: University of Texas Press, 1955.

Oxford English Dictionary. (1933), v. 11

Peterson, Kate. On the Sources of the Nun's Priest's Tale. Boston, 1898.

Sisam, Kenneth. "Introduction." The Nun's Priest's Tale, Geoffrey Chaucer. Ed. Kenneth Sisam. Oxford: The Clarendon Press, 1966.

Speirs, John. Chaucer the Maker. London: Faber \& Faber, 1960. 